\title{
AKTIVITAS ANTIINFLAMASI EKSTRAK ETANOL 70\% DAUN ASHITABA (Angelica keiskei) SECARA IN VIVO DENGAN PENGINDUKSI KARAGENAN
}

\author{
Antiinflamation Activity Of 70\% Ethanol Extract Of Ashitaba Leaf (Angelica Keiskei) \\ In Vivo With Caragenan Induction
}

\author{
Haka As'ada, Yardi Saibi, Hendri Aldrat \\ Program Studi Farmasi-Fakultas IImu Kesehatan UIN- Syarif Hidayatullah Jakarta \\ Jalan Kertamukti No.5, Pisangan, Ciputat, Tangerang Selatan 15412 \\ Email:, yardi@uinjkt.ac.id \\ 081381780975
}

\begin{abstract}
Ashitaba leaves (Angelica keiskei) or also known as tommorow's leaf is plant that known to have various health benefit, one of them is as an anti-inflammatory activity. The antiinflammatory activity of ashitaba leaves has been known through in vitro assays. This study aims to determine the anti-inflammatory activity of $70 \%$ ethanol extract of ashitaba leaves through in vivo assay. Anti-inflammatory activity was performed on white male rat of Sprague dawley strain with induction method of edema on rat's foot using $1 \%$ carrageenan $0.2 \mathrm{ml}$. Rats were divided into 5 groups. The negative control group was given a $0.5 \% \mathrm{Na}-\mathrm{CMC}$ suspension, a positive control group was given sodium diclofenac suspension of $5.14 \mathrm{mg} /$ $\mathrm{kgBW}$, and the test group was given $70 \%$ ethanol extract of ashitaba leaves at a dose of 1000; 2000; and $4000 \mathrm{mg} / \mathrm{kgBW}$ suspended in $0.5 \% \mathrm{Na}-\mathrm{CMC}$. The results showed that in that dose range the $70 \%$ ethanol extract of ashitaba leaves had anti-inflammatory activity that did not depend on the dose. Percentage of edema of $70 \%$ ethanol extract of ashitaba leaves dose 1000; 2000; 4000 mg / kgBB was significantly different with negative control $(p \leq 0,05)$ and had percentage of edema inhibition respectively $83,95 \%, 79,01 \%$, and $80,25 \%$. The results of this study showed that $70 \%$ ethanol extract of ashitaba leaves have anti-inflammatory activity.
\end{abstract}

Keywords: Ashitaba, Angelica keiskei, tommorow's leaf, anti-inflammatory, carrageenan.

\begin{abstract}
Abstrak
Daun ashitaba (Angelica keiskel) atau juga dikenal dengan tommorow's leaf merupakan salah satu tanaman yang dikenal memiliki berbagai khasiat, salah satunya ialah sebagai antiinflamasi. Aktivitas antiinflamasi dari daun ashitaba telah diketahui melalui uji in vitro. Penelitian ini bertujuan untuk mengetahui aktivitas antiinflamasi dari esktrak etanol $70 \%$ daun ashitaba secara in vivo. Uji aktivitas antiinflamasi dilakukan pada tikus putih jantan galur Sprague dawley dengan metode induksi udema pada telapak kaki tikus menggunakan karagenan $1 \%$ sebanyak $0,2 \mathrm{ml}$. Hewan uji dibagi menjadi 5 kelompok. Kelompok kontrol negatif diberikan suspensi Na-CMC 0,5\%, kelompok kontrol positif diberikan suspensi natrium diklofenak 5,14 mg/kgBB, dan kelompok uji diberikan ekstrak etanol $70 \%$ daun ashitaba dengan dosis 1000; 2000; dan 4000 mg/kgBB yang disuspensikan dalam $\mathrm{Na}-\mathrm{CMC} 0,5 \%$. Hasil penelitian menunjukkan bahwa pada rentang dosis tersebut ekstrak etanol $70 \%$ daun ashitaba memiliki aktivitas antiinflamasi yang tidak bergantung pada dosis. Presentase udema ekstak etanol $70 \%$ daun ashitaba dosis 1000; 2000; $4000 \mathrm{mg} / \mathrm{kgBB}$ berbeda signifikan dengan kontrol negatif $(p \leq 0,05)$ dan memiliki nilai persentase inhibisi udema berturut-turut sebesar
\end{abstract}


$83,95 \%, 79,01 \%$, dan $80,25 \%$. Hasil dari penelitian ini menunjukkan bahwa ekstrak etanol $70 \%$ daun ashitaba memiliki aktivitas antiinflamasi.

Kata Kunci: kata Ashitaba, Angelica keiskei, tommorow's leaf, antiinflamasi

\section{PENDAHULUAN}

Inflamasi atau radang merupakan proses respon tubuh terhadap rangsangan merugikan yang ditimbulkan oleh berbagai agen berbahaya seperti infeksi, antibodi, ataupun luka fisik. Inflamasi kronis seringkali menyebabkan ketidaknyamanan dan berpotensi menjadi penyebab terjadinya penyakit lain. Untuk menanggulangi hal itu diberikan suatu obat antiinflamasi. Obat anti inflamasi non steroid (OAINS) merupakan golongan obat yang sering digunakan dalam terapi inflamasi. Aktivitas anti inflamasi OAINS dimediasi melalui penghambatan biosintesis prostaglandin. Efek samping mayor yang dapat timbul akibat konsumsi OAINS ialah iritasi dan ulserasi pada gastrointestinal(1). Oleh karena itu, perlu dilakukan pencarian dan pengembangan obat anti inflamasi baru dengan efek yang sama atau lebih baik dengan efek samping yang minimum. Dalam hal ini, para peneliti telah banyak menggunakan obat dari bahan alam sebagai salah satu solusi, salah satunya tumbuhan ashitaba.

Ashitaba merupakan tumbuhan tradisional yang berasal dari Jepang dan dikenal mempunyai banyak manfaat kesehatan. Tumbuhan tradisional tersebut telah diketahui mempunyai beragam manfaat kesehatan, diantaranya dapat berkhasiat sebagai antibakteri (2), vasodilator (3), antidiabetes (4), antitumor (5), antioksidan (6) dan juga sebagai antiinflamasi(7). Dalam sebuah review tentang efek farmakologis dari tanaman ashitaba menyebutkan bahwa senyawa kalkon merupakan salah satu senyawa yang terkandung dalam ashitaba yang berperan penting dalam efek farmakologisnya (8). Senyawa ini banyak terdapat pada daun dan batang tanaman ashitaba, termasuk diantaranya xantoangeol dan 4hidroxyricine. Senyawa inilah yang membedakan ashitaba dengan tanaman sejenisnya dan telah diketahui senyawa ini dapat bekerja sebagai anti inflamasi (9).

Pada penelitian sebelumnya, (7) telah membuktikan bahwa tanaman ashitaba memiliki aktivitas antiinflamasi secara in vitro. Pada penelitian ini dilakukan uji aktivitas antiinflamasi ekstrak etanol $70 \%$ daun ashitaba secara in vivo dengan metode induksi karagenan.

\section{METODE PENELITIAN}

\section{Alat}

Alat yang digunakan pada penelitian ini antara lain neraca analitik, blender, alat destilasi, spatula, alumunium foil, kapas, kertas saring, lemari pendingin, desikator, alat-alat gelas (erlenmeyer, gelas ukur, dsb), microwave, rotary evaporator, kandang hewan, timbangan hewan, spuit, pipet tetes, sonde, pletismometer

\section{Bahan}

Bahan yang digunakan pada penelitian ini antara lain daun ashitaba (Angelica keiskel), etanol $70 \%$, aquadest, natrium diklofenak (Sigma Aldrich), Na-CMC 0,5\%, karagenan, air raksa, $\mathrm{NaCl}$ Fisiologis 0,9\%, alkohol $70 \%$, dan eter, daun ashitaba.

\section{Hewan Uji}

Tikus putih jantan Rattus novergicus galur Sprague-Dawley dengan bobot $150-250$ gram usia 2 - 4 bulan sebanyak 30 ekor diperoleh dari Institut Pertanian Bogor. Hewan uji dibagi menjadi 5 kelompok 
masing - masing kelompok terdiri dari 5 ekor tikus.

\section{Prosedur}

\section{Pembuatan Suspensi Ekstrak Daun Ashitaba}

Suspensi esktrak etanol $70 \%$ daun ashitaba dibuat dengan mensuspensikan esktrak dalam Na-CMC 0,5\%. Suspensi dibuat sebanyak $20 \mathrm{ml}$ dengan dosis ekstrak 1000, 2000, dan 4000 (mg/kgBB). Pemilihan dosis didasarkan pada hasil uji pendahuluan terhadap tiga kelompok dosis yakni 10, 100 dan $1000 \mathrm{mg} / \mathrm{kgBB}$ yang menunjukkan bahwa dosis 1000 memberikan efek yang paling mendekati kontrol positif.

\section{Uji Aktivitas Antiinflamasi}

Aktivitas antiinflamasi dari ekstrak diuji dengan metode telapak kaki tikus terinduksi karagenan dan dihitung dengan alat pletismometer (10). Penggunaan metode ini didasarkan atas perlakuannya yang sederhana, mudah dilakukan, dan lebih aman karena karagenan mampu menstimulasi udema tanpa menyebabkan cedera atau kerusakan jaringan pada telapak kaki tikus, sehingga metode ini merupakan metode yang sering digunakan dalam pengujian aktivitas antiinflamasi secara in vivo. Hewan uji dikelompokkan menjadi 5 kelompok; (i) Kelompok pertama ialah kontrol negatif yang diberikan suspensi Na-CMC 0,5\%; (ii) Kelompok kedua ialah kontrol positif yang diberikan suspensi natrium diklofenak $5,14 \mathrm{mg} / \mathrm{kg}$ secara oral; (iii) Kelompok 3, 4, dan 5 diberikan suspensi ekstrak etanol $70 \%$ daun ashitaba secara oral dengan dosis 1000,2000 , dan 4000 mg/kg. Setiap kelompok terdiri dari 5 ekor tikus. Penentuan dosis 1000 mg, didasarkan pada uji pendahuluan dimana terhadap tiga dosis yakni $10 \mathrm{mg}, 100 \mathrm{mg}$ dan $1000 \mathrm{mg}$ yang diuji, dosis $1000 \mathrm{mg}$ memperlihatkan hasil yang paling baik.

Hewan uji yang telah diaklimatisasi dan ditimbang bobotnya diukur volume telapak kaki kirinya untuk mendapatkan nilai Vo. Kemudian setiap kelompok diberikan perlakuan oral ( $\mathrm{Na}-\mathrm{CMC} \quad 0,5 \%$ untuk kelompok kontrol negatif; suspensi natrium diklofenak $5,14 \mathrm{mg} / \mathrm{kg}$ untuk kelompok kontrol positif; suspensi ekstrak etanol $70 \%$ daun ashitaba untuk kelompok uji). Karagenan $1 \%$ sebanyak $0,2 \mathrm{ml}$ diinjeksi ke dalam telapak kaki kiri tikus secara subplantar 1 jam setelah pemberian perlakuan oral. Volume telapak kaki tikus diukur dengan menggunakan pletismometer. Pengukuran dilakukan setiap 1 jam hingga 5 jam setelah injeksi.

Udema telapak kaki diartikan sebagai perubahan volume yang terjadi pada telapak kaki tikus setelah diinjeksi karagenan. Persen udema dihitung dengan rumus sebagai berikut ( Vt - Vo)/Vo $\mathrm{x}$ $100 \%$, dimana Vt ialah volume telapak kaki tikus pada jam ke $t$ setelah injeksi karagenan, dan Vo ialah volume awal telapak kaki tikus. Kemudian dari data persen udema dihitung nilai persen inhibisi udema dengan rumus berikut $(A-B) / A x$ $100 \%$, dimana $A$ ialah rata-rata persen udema kelompok kontrol negatif dan B ialah rata-rata persen udema kelomok uji.

\section{Analisa Data}

Data yang diperoleh dihitung secara statistik dengan metode Kruskal-Wallis dan dilanjutkan dengan metode Mann-Whitney dengan level kepercayaan 95\% $(p<0.05)$ menggunakan aplikasi SPSS versi 22.0.

\section{HASIL DAN PEMBAHASAN}

\section{Pengumpulan Sampel dan Ekstraksi}

Sebanyak $7 \mathrm{~kg}$ daun ashitaba yang diperoleh dari Balai Tanaman Manoko Bandung dan telah dideterminasi di Pusat Konversi Tumbuhan Kebun Raya, LIPI, Bogor menghasilkan simplisia sebanyak $1,1 \mathrm{~kg}$ daun ashitaba. Proses ekstraksi menghasilkan ekstrak etanol $70 \%$ daun ashitaba sebanyak $130 \mathrm{gr}$ dengan rendemen sebesar $11,81 \%$. 


\section{Uji Aktivitas Antiinflamasi Ekstrak Etanol 70\% Daun Ashitaba}

Pengujian aktivitas antiinflamasi pada penelitian ini dilakukan secara in vivo dengan metode pengukuran udema telapak kaki tikus yang diinduksi karagenan (10). Grafik 1 menunjukkan rerata volume udema telapak kaki tikus. Kelompok kontrol negatif menunjukkan peningkatan volume udema dari jam pertama hingga jam ke-5. Hal ini menunjukkan tidak adanya aktivitas penghambatan udema yang dihasilkan oleh $\mathrm{Na}-\mathrm{CMC} 0,5 \%$. Nilai persen udema dapat diketahui dari data volume udema. Nilai persen udema ini digunakan untuk melihat adanya peningkatan ataupun penurunan volume udema tanpa dipengaruhi oleh volume awal atau volume normal telapak kaki tikus. Rerata persen udema masing-masing kelompok dapat dilihat pada Grafik 2. Terlihat nilai persen udema pada kelompok kontrol negatif menunjukkan kenaikan secara konstan hingga jam ke-5. Hal ini menunjukkan bahwa karagenan 1\% dengan volume penyuntikan $0,2 \mathrm{ml}$ merupakan agen pendinduksi udema yang baik dan dapat menimbulkan udema yang signifikan. Adanya peningkatan udema hingga jam ke-5 ini juga berhubungan dengan durasi kerja karagenan dalam mendinguksi udema yang mampu bertahan sampai 6 jam(11).

Hasil analisa data statistik menunjukkan bahwa persentase udema kelompok uji dosis 1000; 2000; dan 4000 mg/kg berbeda secara bermakna dengan kontrol negatif ( $p$ $\leq 0.05)$. Hal ini menunjukkan bahwa ekstrak etanol $70 \%$ daun ashitaba dosis 1000 ; 2000; dan 4000 mg/kg aktif sebagai agen antiinflamasi. Sedangkan jika dibandingkan dengan kontrol positif, ketiga dosis uji memiliki perbedaan yang bervariasi. Kelompok uji dosis $1000 \mathrm{mg} / \mathrm{kg}$ berbeda secara bermakna dengan kontrol positif pada jam ke-1 hingga jam ke-3 ( $p$ $\geq 0.05$ ); Kelompok uji dosis $2000 \mathrm{mg} / \mathrm{kg}$ berbeda secara bermakna dengan kontrol positif pada jam ke-2 hingga jam ke-5 ( $p$ $\geq 0.05$ ); dan kelompok uji dosis $4000 \mathrm{mg} / \mathrm{kg}$ berbeda secara bermakna dengan kontrol positif hanya pada jam ke-5 ( $p \geq 0.05)$. Hal ini menunjukkan bahwa dosis uji 4000 $\mathrm{mg} / \mathrm{kg}$ memiliki aktivitas antiinflamasi yang paling mendekati kontrol positif dibanding dosis uji lain karena tidak berbeda secara bermakna mulai jam ke-1 hingga jam ke-4 $(p \leq 0.05)$.

Data rerata persen udema dapat digunakan untuk menentukan nilai penghambatan (inhibisi) udema pada masing-masing kelompok. Data inhibisi ini menunjukkan kemampuan dari masingmasing kelompok dalam menghambat udema pada telapak kaki tikus. Hasil persentase inhibisi udema dapat dilihat pada Tabel 1. Data persen inhibisi udema menunjukkan bahwa kelompok dengan nilai persen inhibisi udema terbesar ialah kelompok kontrol positif sebasar $90,12 \%$, disusul kelompok dosis uji 1000, 4000, dan $2000 \mathrm{mg} / \mathrm{kg}$ dengan nilai persen inhbisi udema masing-masing kelompok secara berurutan sebesar 83,95\%, 80,24\%, dan $79,01 \%$. Hubungan nilai persen inhibisi udema antarkelompok dengan waktu pengukuran dapat dilihat pada Grafik 3.

Kelompok uji dosis $4000 \mathrm{mg} / \mathrm{kg}$ memiliki nilai persen inhbisi paling tinggi diantara kelompok dosis uji lain pada jam ke-1 hingga jam ke-3. Sedangkan pada jam ke4 dan ke-5 kelompok uji yang memiliki nilai persen inhibisi paling tinggi ialah kelompok uji dosis $1000 \mathrm{mg} / \mathrm{kg}$. Berdasarkan mekanisme kerja dari karagenan dalam menimbulkan udema, kelompok uji dosis $4000 \mathrm{mg} / \mathrm{kg}$ kemungkinan memiliki aktivitas penghambatan bradikinin lebih tinggi dibanding kelompok uji lain, dan kelompok uji dosis $1000 \mathrm{mg} / \mathrm{kg}$ kemungkinan memiliki aktivitas penghambatan protaglandin lebih tinggi dibandingkan kedua kelompok uji lainnya (12). Hasil analisa data statistik menunjukkan bahwa perbandingan antara ketiga kelompok uji memiliki perbedaan yang tidak bermakna $(p \geq 0.05)$. 


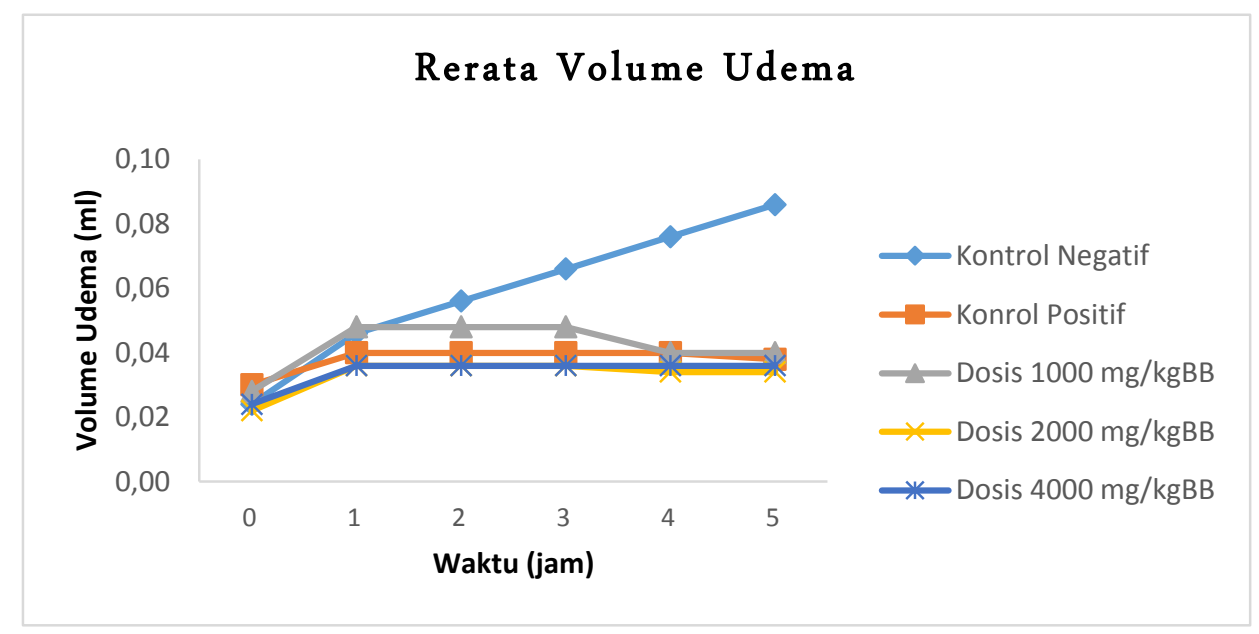

Grafik 1. Grafik rerata volume udema

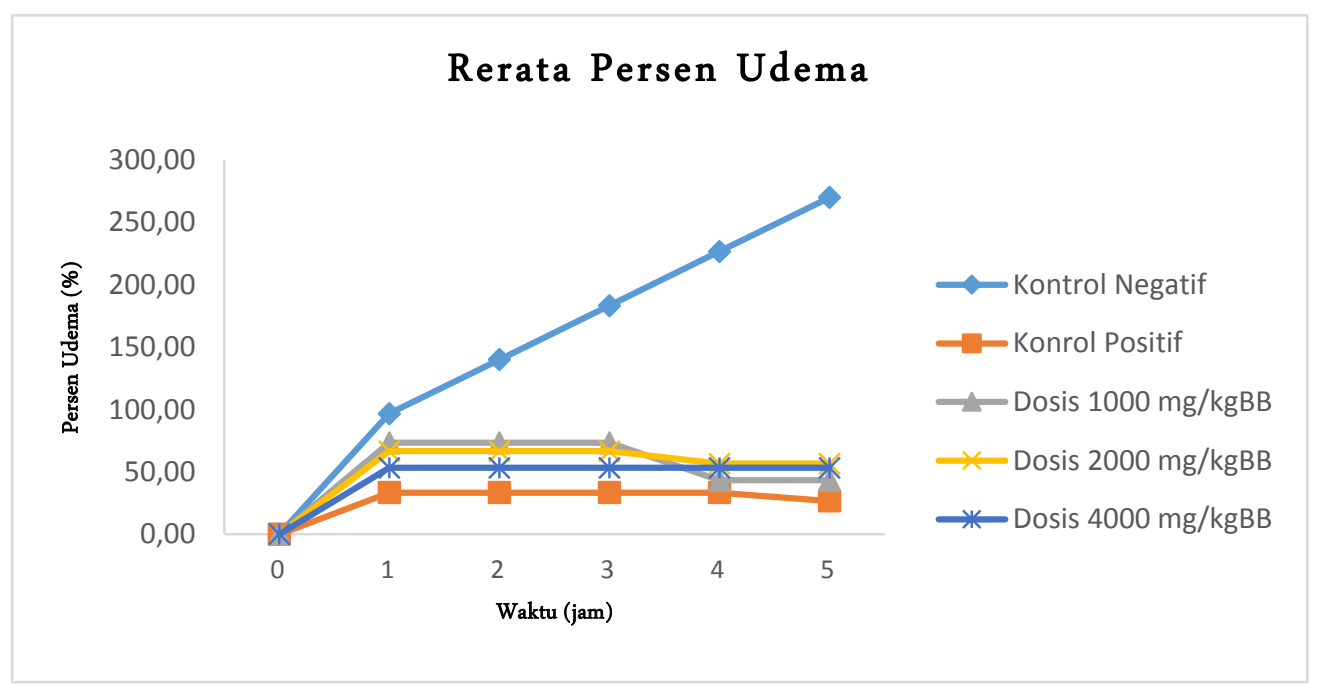

Grafik 2. Grafik rerata persen udema

Tabel 1. Persen inhibisi udema

\begin{tabular}{llllll}
\hline \multirow{2}{*}{ Kelompok } & \multicolumn{7}{c}{ Persen Inhibisi Udema Jam ke- (\%) } \\
\cline { 2 - 6 } & $\mathbf{1}$ & $\mathbf{2}$ & $\mathbf{3}$ & $\mathbf{4}$ & $\mathbf{5}$ \\
\hline Kontrol Positif (Na-diklofenak & & & & \\
$5,14 \mathrm{mg} / \mathrm{kgBB})$ & 65,52 & 76,19 & 81.82 & 85.29 & 90.12 \\
Dosis $1000 \mathrm{mg} / \mathrm{kgBB}$ & 24.14 & 47.62 & 60.00 & 80.88 & 83.95 \\
Dosis $2000 \mathrm{mg} / \mathrm{kgBB}$ & 31.03 & 52.38 & 63.64 & 75.00 & 79.01 \\
Dosis 4000 mg/kgBB & 44.83 & 61.90 & 70.91 & 76.47 & 80.25 \\
\hline
\end{tabular}




\section{KESIMPULAN DAN SARAN}

\section{KESIMPULAN}

Ekstrak etanol $70 \%$ daun ashitaba dosis $1000 \mathrm{mg} / \mathrm{kgBB}, 2000 \mathrm{mg} / \mathrm{kgBB}$, dan 4000 $\mathrm{mg} / \mathrm{kgBB}$ mampu menghambat pembentukan udema pada telapak kaki tikus dan aktif sebagai agen antiinflamasi secara in vivo yang belum setara dengan kontrol positif (natrium diklofenak). Ekstrak etanol $70 \%$ daun ashitaba dosis 1000 $\mathrm{mg} / \mathrm{kgBB}$ memiliki aktivitas antiinflamasi paling baik dibandingkan dosis 2000 $\mathrm{mg} / \mathrm{kgBB}$ dan $4000 \mathrm{mg} / \mathrm{kgBB}$. Hasil analisis data statistik aktivitas antiinflamasi ekstrak etanol $70 \%$ daun ashitaba dosis 1000 $\mathrm{mg} / \mathrm{kgBB}, 2000 \mathrm{mg} / \mathrm{kgBB}$, dan 4000 $\mathrm{mg} / \mathrm{kgBB}$ memiliki perbedaan yang tidak bermakna $(p \geq 0,05)$.

\section{DAFTAR PUSTAKA}

[1] Tilo Grosser, Emer Smith GAF. Goodman \& Gilman's. 2011. The Pharmacological Basis of Therapeutics. p. 959-1000.

[2] Inamori $\mathrm{Y}$, Baba $\mathrm{K}$, Tsujibo $\mathrm{H}$, Taniguchi M, Nakata K, Kozawa M. 1991. Antibacterial Activity of Two Chalcones, Xanthoangelol and 4Hydroxyderricin, Isolated from the Root of Angelica keiskei Koidzumi. Chem Pharm Bull. 39(6):1604-5.

[3] Matsuura M, Kimura Y, Nakata K, Baba K, Okuda H. 2001. Artery Relaxation Chalcones Isolated from the Roots of Angelica keiskei. Planta Med. 2000;67:230-5.

[4] Ugiyama KAS, Anabe MAT, Obayashi EIJIK. 2007. Antidiabetic Activities of Chalcones Isolated from a Japanese Herb , Angelica keiskei. J.Agric FoodChem. 55:6013-7.

[5] Kimura Y. 2008. Antitumor and Antimetastatic Actions of Various Natural Products. Stud Nat Prod Chem. 34(C):35-76.
[6] Kwon D, Yoon S, Carter O, Bailey GS. 2006. Antioxidant and antigenotoxic activities of Angelica keiskei , Oenanthe javanica and Brassica oleracea in the Salmonella mutagenicity assay and in HCT116 human colon cancer cells. Bio Farctors .26.26:231-44.

[7] Lee HJ, Kim HJ, Choi S, Kim S, Sethi G, Ahn KS. 2010. 1111. ;13(3):691-9.

[8] Caesar LK, Cech NB. 2006. A Review of the Medicinal Uses and Pharmacology of Ashitaba. Planta med.

[9] Hsieh H, Tsao L, Wang J. 2006. Synthesis and Anti-in - ammatory Effect of Chalcones. J Pharm Pharmacol. 52:163-71.

[10] Winter CA, Risley EA, Nuss GW. 1962. Carrageenin-Induced Edema in Hind Paw of Rat as an Assay for Antiinflammatory Drugs. Exp Biol Med. 1-5.

[11] Morris CJ. 2003. Carrageenaninduced paw edema in the rat and mouse. Methods Mol Biol. 225:11521. 